\title{
Microhabitat selection and colonization rates of a benthic amphipod
}

\author{
Theodore H. DeWitt*
}

Department of Ecology and Evolution, State University of New York at Stony Brook, Stony Brook, New York 11794, USA

\begin{abstract}
Microhabitat selection behavior and colonization rates were examined for 2 age classes and sexes of the nocturnally emergent, diurnally tubicolous amphipod Microdeutopus gryllotalpa. Three habitat variables were studied: food availability, sediment thickness, and topographic relief. Higher food concentration, deeper sediment, and greater topographic relief were generally favored. Adult males and females made similar habitat choices, whereas juveniles were less discriminating. Both age classes colonized selected patches within 5 to $20 \mathrm{~min}$ of presentation to a choice of habitats, and both generally sustained their choices for at least $72 \mathrm{~h}$ in the laboratory. Microhabitat selections in field experiments were similar to those in laboratory experiments. Field colonization rates of 0.06 and 0.17 amphipods $\mathrm{cm}^{-2}$ per day and night, respectively, were comparable to rates of larval and postlarval colonization reported in other studies. High rates of nocturnal mobility and colonization, and rapid discrimination of microhabitats observed in this and other benthic species suggest that contemporary models of benthic community structure need to incorporate these migratory and colonization behaviors as alternatives to mortality as responses to disturbance, competitors, or predators.
\end{abstract}

\section{INTRODUCTION}

Many models of benthic community structure hold that species distributions result from larval dispersal and colonization, followed by adult and juvenile mortality caused by predation, disturbance, or competition (Thorson 1966, Rhoads \& Young 1970, Peterson 1977. Woodin 1978). These models assume that juveniles and adults are relatively passive, sedentary parcels whose fate depends on the temporal and spatial distribution of these processes. However, these models rarely consider the ability of benthic invertebrates to influence their own distributions through post-larval migration and habitat selection.

Studies from diverse geographic regions show that juveniles and adults of many benthic invertebrates emigrate frequently, generally nocturnally (e.g. Williams \& Bynum 1972, Alldredge \& King 1977, 1980, Robertson \& Howard 1978), and recolonize benthic sediments rapidly (Alldredge \& King 1980, VanBlaricom 1982, Bell \& Devlin 1983, Oliver \& Slattery 1985). Emigration by adults and juveniles may be a response

- Present address: E.P.A. Environmental Research Laboratory, Hatfield Marine Science Center, Newport, Oregon 97365, USA to predators (Ambrose 1984), disturbance (DeWitt \& Levinton 1985, Jensen 1985), poor habitat conditions (DeWitt 1985), reproduction (Anger \& Valentin 1976), crowding (Ambrose 1986), or other unexamined factors. Emigrants entering the water column may be carried considerable distances (i.e. meters to kilometers) away from their former habitats (Alldredge \& King 1977 , Dean 1978a, b, Virnstein \& Curran 1986). Others may only move a few centimeters above the substratum and experience little lateral movement. Other animals may never leave the sediment, but burrow laterally (Oakden et al. 1984) or crawl across the sediment surface. Although benthic invertebrates may be passively suspended in the water column due to storm or wave turbulence (Sherman \& Coull 1980, Dobbs \& Vozarik 1983), regular excursions out of the sediment can involve up to $80 \%$ of some populations or over $10 \%$ of the total community every night (Anger \& Valentin 1976, Walters \& Bell 1986).

Considerable work on habitat selection behavior has shown that many benthic species discriminate among potential microhabitats (see review by Meadows \& Campbell 1972). In laboratory studies, many cues have been shown to influence habitat selection, including sedimentary habitat features such as food, sediment depth, and sediment particle size (Meadows \& Camp- 
bell 1972), disturbance from habitat residents (DeWitt \& Levinton 1985), and pollutants (Åkesson \& Ehrenström 1984, Oakden et al. 1984). Except for the work of Stretch $(1983,1985)$, little work has been conducted in the field on patch selection by adult or juvenile invertebrates. Even less is known of the rates at which invertebrates choose among habitat patches. Most studies examine patch selection over periods of days (see references in Meadows \& Campbell 1972), but not over shorter periods (i.e. minutes to hours). Rapid selection of microhabitats should be more relevant to the behavior of nocturnal emigrants that spend only a few hours, or less, away from the substratum (Alldredge \& King 1980, Dauer et al. 1982, Ohlhorst 1982). In addition, few previous studies have investigated intraspecific variation in colonization behavior (Beukema \& de Vlas 1979), which could have significant impact on population demographics within microhabitat patches.

In this study, I examined microhabitat selection behavior of the tubicolous amphipod Microdeutopus gryllotalpa with respect to the amount of food in a patch, the thickness of a patch of sediment, and the topographic relief created by solid structures imbedded or underlying the sediment. The experiments were designed to determine (1) the ranges of each habitat feature that the amphipods respond to, above or below which colonists do not distinguish between patches, (2) the rates at which amphipods choose and colonize patches, (3) how amphipods choose patches that vary with respect to 2 different habitat variables presented simulaneously, and (4) sex or age related variation in microhabitat selection behavior.

\section{METHODS}

The microhabitat selection behavior of Microdeutopus gryllotalpa was examined by manipulating food abundance, sediment thickness, and topographic relief within experimental arenas. All laboratory experiments were conducted within constant-temperature environmental chambers maintained at $15^{\circ} \mathrm{C}$ $\left( \pm 2^{\circ}\right)$ with a $14 \mathrm{~h}$ light: $10 \mathrm{~h}$ dark photoperiod. The salinity of the water in the arenas was adjusted to $26 \%$ ( $\pm 3 \%$ ). Field manipulations were performed subsequently to test the validity of the laboratory results and to measure microhabitat patch colonization rates.

Microdeutopus gryllotalpa Costa is a tubicolous, aorid amphipod common to quiet, shallow, subtidal benthic habitats in southern New England (Bousfield 1973) and western Europe (Myers 1969). It is found in pristine and polluted habitats, occurs in salinities ranging from $<5$ to $33 \%$, and is active all year in temperatures ranging from 5 to $22^{\circ} \mathrm{C}$ (Parker 1975, author's obs.). Its field habitats include muddy substrates, eelgrass blades, mussel clumps, pilings, and floating docks. $M$. gryllotalpa has a relatively short generation time (ca 6 to $8 \mathrm{wk}$ ); mature females produce young at 6 to $10 \mathrm{~d}$ intervals (Myers 1971, author's obs.).

Microdeutopus gryllotalpa was maintained in continuous culture for over $4 \mathrm{yr}$ in a recirculating seawater system maintained at approximately the same temperature, salinity, and photoperiod as the environmental chamber and arenas. The initial population and subsequent additions were collected from floating docks and salt marshes along the north shore of Long Island, New York, and Jamaica Bay, Brooklyn, New York, USA. M. gryllotalpa survived well in the laboratory, sustaining high densities (ca $2 \mathrm{~cm}^{-2}$ ) with minimal maintenance.

Body length was measured by computer digitization of a camera lucida image of each amphipod. Three mm total length (base of the first antennae to the base of the urosome) defined the cutoff between adults and juveniles as this is approximately the size of the smallest gravid females and the size at which adult male characteristics are discernible (spines on the propod of the first gnathopod; Myers 1969). Sexes were distinguished by the larger, spinous first gnathopods of males and the presence of eggs in female brood chambers.

Laboratory experiments. Arenas. Four arena types were employed (Fig. 1); most experiments were conducted in $14.0 \mathrm{~cm}$ diameter Petri dishes. The bottoms of
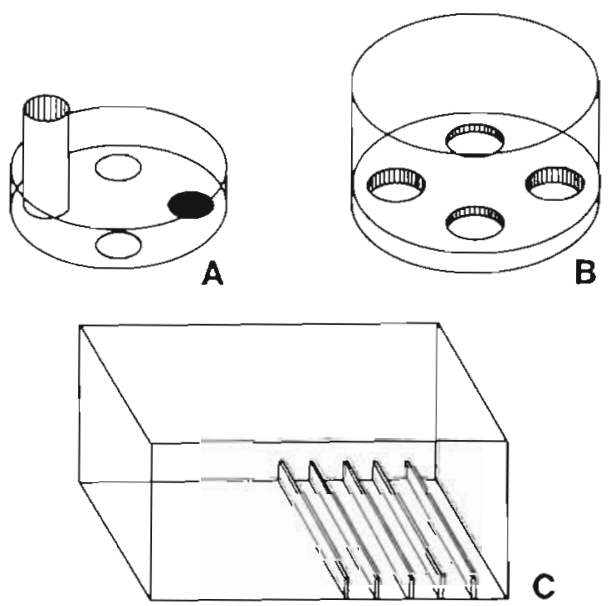

Fig. 1. Experimental arenas. (A) Petri dish arena $(8.25 \mathrm{~cm}$ or $14.0 \mathrm{~cm}$ diameter) with 3 circular sediment patches and a patch template cylinder over a 4th patch. (B) Black dish arena $(22.8 \mathrm{~cm}$ diameter $\times 9.5 \mathrm{~cm}$ height) with 4 sediment-depth wells. (C) Freezer-box arena $(18.8 \mathrm{~cm} \times 13.2 \mathrm{~cm} \times 6.0 \mathrm{~cm}$ height) with wood-strip crevices on right

all arenas, except the freezer boxes, were bare except for the microhabitat sediment patches (described below). In the freezer boxes, 2 equal-area habitat patches covered the bottom of the arena. Wooden strips 
( $5 \mathrm{~mm}$ high $\times 1 \mathrm{~mm}$ wide) were glued to the bottom of the freezer boxes to create topographic relief. Bottoms of the black dishes had a $1.5 \mathrm{~cm}$ paraffin-sand layer into which four $6.2 \mathrm{~cm}$ diameter wells of specific depth were cast for sediment depth choice experiments. Sediment was added to each well, allowed to settle for $>6 \mathrm{~h}$, and leveled flush with the arena floor. Each large Petri dish arena $(14.0 \mathrm{~cm}$ diameter $)$ held 4 patches $4.8 \mathrm{~cm}$ in diameter, whereas the small Petri dish arenas $(8.25 \mathrm{~cm}$ diameter) held two to four $1.5 \mathrm{~cm}$ diameter patches. Patches in all arenas (except freezer boxes) were physically separated from each other by at least $1 \mathrm{~cm}$ and did not touch the arena walls.

Sediment, microhabitat patches, and food. Sediment was collected from a local salt marsh, Flax Pond (Old Field, New York), sieved through a $250 \mu \mathrm{m}$ screen, and frozen for at least $24 \mathrm{~h}$. This sediment was maintained for 4 to $6 \mathrm{mo}$ in a recirculating seawater system in darkness (hereafter referred to as DCS for darkcultured sediment) to stifle the growth of microalgae; this produced a sediment with a relatively low background chlorophyll a content (4.3 [SD \pm 0.5$] \mu \mathrm{g}$ chl a $\mathrm{mg}^{-1}$ dry sediment).

Replicate microhabitat sediment patches of equal thickness were created by pipetting equal volume aliquots (0.1 to $5 \mathrm{ml}$ ) of homogenously mixed sediment (1) simultaneously into each half of a freezer box arena, (2) into each well cut into the bottom of the black dish arenas, or (3) into a 'patch template' (4 to $10 \mathrm{~cm}$ tall open-ended plastic cylinders, $1.5 \mathrm{~cm}$ or $4.8 \mathrm{~cm}$ diameter; Fig. 1A) placed on the floor of a Petri dish arena. Sediment was allowed to settle for $\geq 6 \mathrm{~h}$ prior to the addition of amphipods. Patches were $1 \mathrm{~mm}$ thick unless otherwise noted. Standard patch diameter was $4.8 \mathrm{~cm}\left(18.1 \mathrm{~cm}^{2}\right)$. Sediment depth in a patch was determined using the regression equation: Sediment depth $(\mathrm{mm})=0.194+20.52 \mathrm{X}-6.87 \mathrm{X}^{2}\left(\mathrm{r}^{2}=0.86, \mathrm{p} \leq 0.001\right)$ where $X=$ dry wt sediment/area (in $\mathrm{gm} \mathrm{cm}^{-2}$ ). This equation was derived empirically prior to the patch choice experiments.

Initial experiments (reported below) and observations indicated that Microdeutopus gryllotalpa was a deposit feeder and utilized microalgae among other sediment microflora. For most experiments, food abundance was adjusted by varying the volume of OMA (organic mineral aggregates, sensu Johnson [1974] and Weinberg [1979]) added to sediments. OMA is a flocculent assemblage of sediment grains imbedded in a matrix of organic matter and microflora (Johnson 1974), and was collected as the fine sediment settling out of the water column in a recirculating seawater system. OMA was sieved through a $150 \mu \mathrm{m}$ screen, homogenized, and frozen in $5.0 \mathrm{ml}$ aliquots at $-50^{\circ} \mathrm{C}$. Prior to use, aliquots were thawed, mixed, and resieved through a $150 \mu \mathrm{m}$ screen. Sediment chloro- phyll a was used as a measure of the food value of OMA and sediments, and was determined fluorometrically (Strickland \& Parsons 1969, Vollenweider 1969).

Standard experimental design. Choice experiments generally consisted of pairs of patches of contrasting amounts of a single habitat feature (i.e. 2 food concentrations, 2 sediment depths, or 2 crevice widths or heights) set in large Petri dish arenas. Two patches (4.8 $\mathrm{cm}$ diameter, $1 \mathrm{~mm}$ thick) of each habitat treatment were created, resulting in a total of 4 patches per arena (Fig. $1 \mathrm{~A}$ ). In one set of experiments, 2 habitat variables (food and depth) were varied independently among patch treatments. Typically, 20 amphipods of a given age or sex were added to each arena and patch choices determined after $24 \mathrm{~h}$. Exceptions to these conditions and further details are provided in the table and figure legends summarizing the results of each experiment.

Individuals were pipetted gently into an acclimation chamber (an upright hollow cylinder) in the center of each arena for ca $30 \mathrm{~min}$ before release. Amphipod densities were kept low $\left(\leq 1 \mathrm{~cm}^{-2}\right.$ for adults, $\leq 2 \mathrm{~cm}^{-2}$ for juveniles) to minimize intraspecific competition for space. The number of amphipods colonizing a patch was determined by the number of occupied tubes in a patch or by pipetting and sieving an entire patch through a $250 \mu \mathrm{m}$ mesh screen. Animals not in tubes were not pipetted nor counted as colonists. The proportions of colonists on each patch type are reported in the choice experiments. Observations of patch choice were made either at regular time intervals or at the end of an experiment. Experiments were replicated 4 or more times (unless otherwise noted). Patch choice experiments were analyzed as replicated pairwise comparisons using the replicated goodness-of-fit Gtest procedure (Sokal \& Rohlf 1981).

Patch-choice controls were run for each experiment, consisting of 2 to 4 identical patches. Orientation bias was tested by comparing proportions of colonists on north-south patches with colonists on east-west patches. The orientation of patches in all experiments was rotated $90^{\circ}$ among replicate arenas to reduce orientation bias to light or other external cues. Replicate arenas of each experimental treatment were interspersed in a stratified, systematic design (sensu Hurlbert 1984). No significant orientation or position bias was found in any experiment.

Specific experiments. The microhabitat choice experiments may be divided into 4 general categories: food choice experiments, sediment depth choice experiments, patch choice for topographic relief, and simultaneous choice of 2 habitat variables.

Food choice experiments. (1) Food type: This experiment was designed to determine whether Microdeutopus gryllotalpa discriminated among major types 
of nutrition found in soft sediments (e.g. microflora, macroalgae Ulva lactuca, and animal tissue - represented by the commercial fish food Tetramin, which is a mixture of fish and crustacean meal). (2) Food concentration: This experiment examined whether threshold concentrations of OMA exist below or above which amphipods did not discriminate between sediments. OMA concentrations were $0,1,10$, and $100 \mathrm{ml}$ $(200 \mathrm{ml})^{-1}$ DCS. (3) Rate of patch selection: These experiments measured intraspecific differences in rates of choosing patches of differing food abundance.

Sediment depth patch choice experiment. This experiment examined whether Microdeutopus gryllotalpa discriminated between patches of different sediment thickness, and whether thresholds in sediment depth exists above or below which amphipods did not discriminate between patches of different depth.

Selection for topographic relief. Several experiments examined whether Microdeutopus gryllotalpa would choose between patches on the basis of the presence or amount of micro-topographic relief. Intraspecific differences in choice were also examined. (1) Choice of ridges: Contrasting patches were ridges $(5 \mathrm{~mm}$ high $\times$ $1 \mathrm{~mm}$ wide, spaced $5 \mathrm{~mm}$ apart) and no ridges. Sediment was $2.2 \mathrm{~mm}$ deep. A second experiment examined whether the same ridges would be chosen if covered with $7.7 \mathrm{~mm}$ sediment. (2) Choice of spacing of crevices: Two experiments examined whether the spacing between ridges (i.e. width of crevices: narrow $=5 \mathrm{~mm}$ apart, wide $=10 \mathrm{~mm}$ apart) affected patch choice. In one experiment, crevices of both treatments each occupied one half of the freezer box arena. To control for the increased number of narrow crevices in this experiment, a second experiment used equal numbers of crevices on each half of the arena. (3) Choice of crevice height: This experiment examined whether amphipods distinguished between crevices of varying vertical relief, and if thresholds in the vertical height of crevices exist above or below which amphipods ceased to discriminate between crevice height treatments.

Simultaneous choice between 2 independent habitat variables: mud depth and food concentration. Two sets of experiments examined (1) whether Microdeutopus gryllotalpa discriminates between patches in which 2 habitat features vary independently, and (2) intraspecific variation in the rates of colonizing such patches. (1) Patch choice: Adults were presented with choices between patches differing in both sediment depth and food concentration. Referring to Table 6 , experiments in $\mathrm{A}$ held the absolute amount of food constant between patches (OMA present as a layer on top of DCS patch), but varied patch thickness; experiments $B$ held the concentration of food constant (equal ml OMA g ${ }^{-1}$ DCS), but varied patch thickness; trials C held patch thickness constant and varied the absolute amount of food per patch; and experiment D held patch thickness constant and varied the concentration of food. (2) Interspecific variation in colonization rate: A 3-factorial experiment examined how both food concentration and sediment depth affected rates of patch colonization in amphipods. Groups of male, female, or juvenile amphipods were presented with single patches representing a combination of food concentration (high or low OMA) and sediment thickness (deep or thin DCS).

Field experiments. Colonization rates and microhabitat choices of Microdeutopus gryllotalpa were examined in the field following procedures similar to the laboratory experiments. Microhabitat patches were created in Petri dishes glued to plastic racks, which were then suspended from floating docks (Centerport, Long Island, New York, USA) harboring large numbers of M. gryllotalpa.

Food concentration (high: $46 \mu \mathrm{g} \mathrm{Chl} \mathrm{a} \mathrm{g} \mathrm{g}^{-1}$ sediment;

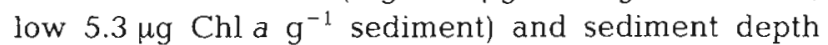
(deep: $4.3 \mathrm{~mm}$; thin: $0.7 \mathrm{~mm}$ ) patches were created in separate, quartered $8.5 \mathrm{~cm}$ diameter arenas. Topographic relief patches (crevice-rich: four $3.5 \mathrm{~cm}$ square pieces of $1 \mathrm{~cm}$ mesh screen covered by $1 \mathrm{~mm}$ of DCS; no crevices: $1 \mathrm{~mm}$ thick patch of DCS, but no screen) were presented in $14 \mathrm{~cm}$ Petri plates. Food concentration and sediment depth arenas were each replicated 5 times, and the topographic relief arenas 6 times.

The racks were suspended $1.5 \mathrm{~m}$ below the water surface and ca $1 \mathrm{~m}$ below the bottom of the floating dock, which had no physical connection with the racks. The racks were suspended during the day (12 h) from 0700 to $1900 \mathrm{~h}$ on 6 and 11 June 1984, and during the night ( $8 \mathrm{~h}$ ) from 2100 to $0500 \mathrm{~h}$ on 5 and 10 June 1984 . At the end of the submersion period, the numbers, sexes, and ages of colonists were determined in each patch.

\section{RESULTS}

\section{Laboratory experiments}

Food choice

(1) Food type: Microdeutopus gryllotalpa selected OMA and Ulva significantly over fish food (Table 1). Ulva was chosen over OMA at low Ulva concentrations, whereas at higher Ulva concentrations the patches were selected approximately equally. Further, a low Ulva concentration was significantly chosen over high UIva concentrations; similar results were observed for high and low concentrations of Tetramin.

(2) Food concentration: Microdeutopus gryllotalpa discriminated among concentrations of OMA, but not 
Table 1. Microdentopus gryllotalpa. Patch selection for food type by mixed groups of adults and juveniles. Cells contain mean percent of individuals on Patch X, SD and significance level. $\mathrm{N}=3$ (each large Petri dish arena containing 15 to 25 amphipods) for all comparisons. Each experiment ran for $24 \mathrm{~h}$. Food concentrations: OMA (organic mineral aggregates) $1.25 \mathrm{ml} \mathrm{mm}^{-1} \mathrm{DCS}_{\text {; }}$ Ulva $1.05 \%$ low \& $9.5 \%$ (high) by wt; Tetramin $1.05 \%$ (low) \& $9.5 \%$ (high) by wt. Control results (along the diagonal) are percent of individuals from the $\mathrm{N}$-S axis of the arena

\begin{tabular}{|c|c|c|c|c|c|}
\hline Patch X & OMA & $\begin{array}{l}\text { Ulva } \\
\text { (low) }\end{array}$ & $\begin{array}{c}\text { Patch Y } \\
\text { Ulva } \\
\text { (high) }\end{array}$ & $\begin{array}{l}\text { Tetramin } \\
\text { (low) }\end{array}$ & $\begin{array}{l}\text { Tetramin } \\
\text { (high) }\end{array}$ \\
\hline OMA & $\begin{array}{c}57.8 \% \\
(10.2) \\
\text { ns }\end{array}$ & $\begin{array}{c}8.26 \% \\
(8.88) \\
p \leq 0.001\end{array}$ & $\begin{array}{c}63.1 \% \\
(20.7) \\
\text { ns }\end{array}$ & $\begin{array}{c}68.1 \% \\
(6.36) \\
\mathrm{p} \leq 0.001\end{array}$ & $\begin{array}{c}95.6 \% \\
(3.85) \\
\leq \leq 0.001\end{array}$ \\
\hline $\begin{array}{l}\text { Ulva } \\
\text { (low) }\end{array}$ & & $\begin{array}{c}45.4 \% \\
(29.97) \\
\text { ns }\end{array}$ & $\begin{array}{r}97.6 \% \\
(4.12) \\
\mathrm{p} \leq 0.001\end{array}$ & $\begin{array}{r}67.5 \% \\
(3.64) \\
\mathrm{p} \leq 0.001\end{array}$ & - \\
\hline $\begin{array}{l}\text { Ulva } \\
\text { (high) }\end{array}$ & & & $\begin{array}{c}61.1 \% \\
(26.33) \\
\text { ns }\end{array}$ & - & $\begin{array}{c}74.3 \% \\
(22.0) \\
p \leq 0.05\end{array}$ \\
\hline $\begin{array}{l}\text { Tetramin } \\
\text { (low) }\end{array}$ & & & & $\begin{array}{c}57.8 \% \\
(26.9) \\
\text { ns }\end{array}$ & $\begin{array}{r}97.6 \% \\
(4.12) \\
\mathrm{p} \leq 0.001\end{array}$ \\
\hline $\begin{array}{l}\text { Tetramin } \\
\text { (high) }\end{array}$ & & & & & $\begin{array}{c}43.81 \% \\
(20.0) \\
\text { ns }\end{array}$ \\
\hline
\end{tabular}

between patches with similar food concentrations (Table 2). Patches with higher food concentrations were always preferred except when concentration differences between patches were small. $M$. gryllotalpa discriminated between $10 \mathrm{ml} O M A$ and $0 \mathrm{ml}$ OMA, but neither between $10 \mathrm{ml}$ OMA and $1 \mathrm{ml} O \mathrm{OMA}$, nor between $1 \mathrm{ml} O M A$ and $0 \mathrm{ml} O M A$. The $1 \mathrm{ml}$ addition of OMA produced so small a change in the microfloral density that no increase in chl a was detected by the fluorometer. The $100 \mathrm{ml}$ OMA patches were chosen over all lower concentrations.

(3) Rate of food patch selection: Adult amphipods built tubes in high food concentration patches rapidly: within $30 \mathrm{~min}, 86 \%$ of all males and females had settled, with ca $62 \%$ of these colonists occupying high food patches (Fig. 2). After 72 h, $95 \%$ of all adults had settled, with ca $80 \%$ of these on high food patches. Amphipods not settled on patches were inactive or

Table 2. Microdeutopus gryllotalpa. Patch choice by adult amphipods as a function of the relative concentration of organic mineral aggregates (OMA). Food concentrations for the 0,1,10, \& 100 OMA treatments were $4,4,18, \& 127 \mu \mathrm{g} \mathrm{Chl} \mathrm{a} \mathrm{g}^{-1} \mathrm{DCS}$.

Experiment ran $24 \mathrm{~h}$

\begin{tabular}{|c|c|c|c|c|c|}
\hline \multicolumn{3}{|c|}{$\mathrm{Ml}$ of OMA added to sediment } & \multicolumn{3}{|c|}{$\begin{array}{l}\text { Percent of individuals } \\
\text { choosing Patch } Y\end{array}$} \\
\hline Patch $X$ & Patch Y & No. of replicates" & Mean & SD & $\begin{array}{c}\text { Significance } \\
\text { level }\end{array}$ \\
\hline 0 & $\begin{array}{r}0 \\
1 \\
10 \\
100\end{array}$ & $\begin{array}{l}4 \\
3 \\
3 \\
3\end{array}$ & $\begin{array}{l}44.5 \\
51.8 \\
70.4 \\
79.9\end{array}$ & $\begin{array}{r}9.41 \\
25.09 \\
31.95 \\
8.80\end{array}$ & $\begin{array}{c}\mathrm{ns} \\
\mathrm{ns} \\
\mathrm{p} \leq 0.001 \\
\mathrm{p} \leq 0.001\end{array}$ \\
\hline 1 & $\begin{array}{r}1 \\
10 \\
100\end{array}$ & $\begin{array}{l}4 \\
3 \\
3\end{array}$ & $\begin{array}{l}56.5 \\
58.8 \\
60.1\end{array}$ & $\begin{array}{r}3.85 \\
25.80 \\
12.17\end{array}$ & $\begin{array}{c}\mathrm{ns} \\
\mathrm{ns} \\
\mathrm{p} \leq 0.01\end{array}$ \\
\hline 10 & $\begin{array}{r}10 \\
100\end{array}$ & $\begin{array}{l}4 \\
3\end{array}$ & $\begin{array}{l}61.4 \\
68.8\end{array}$ & $\begin{array}{l}31.72 \\
11.81\end{array}$ & $\begin{array}{c}\text { ns } \\
p \leq 0.001\end{array}$ \\
\hline 100 & 100 & 4 & 45.5 & 15.65 & ns \\
\hline
\end{tabular}




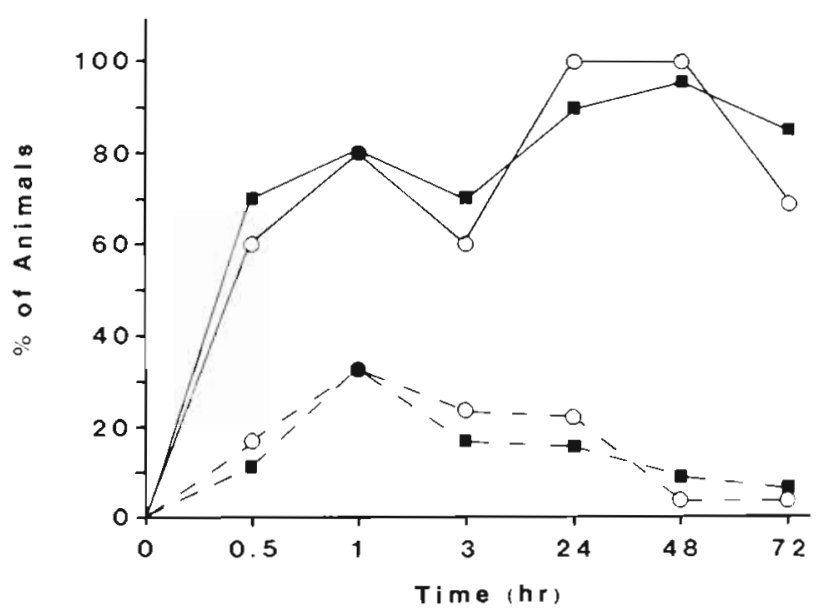

Fig. 2. Microdeutopus gryllotalpa. Sexual differences of adult amphipods in patch choices made over time. Percent of all males ( $\square$ ) and females (O) on high food density patches is shown by solid lines; percent of each sex not colonizing any patch by broken lines. Data are from a single experiment using 27 individual males and 45 individual females so within-time variances could not be estimated

crawling across sediment patches or the arena. Adult males and females selected high food concentration patches and colonized patches at roughly equal rates. Responses of both sexes were highly correlated $(\mathrm{r}=$ $0.948 ; p \leq 0.01$ ) and statistically indistinguishable at each time point (goodness-of-fit G-test; $p>0.05$ ).

Significantly fewer juveniles chose high food patches than did adults (Table 3), although both age classes settled rapidly on high food patches (Fig. 3). Within 5 min, $90.8 \%$ (SD 9.2) of the adults and $76.7 \%$ (SD 11.6) of the juveniles that colonized any patch had settled on high food patches (note that Fig. 3 shows the numbers of all potential colonists occupying high food patches). The patterns of colonization were slightly different for adults and females, accounting for the timexage interaction in the repeated measures ANOVA (Table 3). Peak occupancy occurred between $30 \mathrm{~min}$ and $12 \mathrm{~h}$ and declined subsequently. The decline may have been caused by decreased differences in microfloral concentration between the high

Table 3. Microdeutopus gryllotalpa. Repeated measures design ANOVA comparing numbers of adult and juvenile amphipods choosing high food patches observed at 12 intervals over $72 \mathrm{~h}$. $\mathrm{N}=4$ with 20 adults or 30 juveniles per replicate

\begin{tabular}{|lrccc|}
\hline Source & df & MS & F & Significance \\
\hline Amphipod age & 1 & 1.049 & 43.75 & $\mathrm{p} \leq 0.01$ \\
Error (Age) & 5 & 0.024 & & \\
Time & 11 & 0.007 & 1.83 & $\mathrm{p} \leq 0.05$ \\
Time $\times$ Age & 11 & 0.017 & 4.41 & $\mathrm{p} \leq 0.05$ \\
Error (time) & 55 & 0.004 & & \\
\hline
\end{tabular}

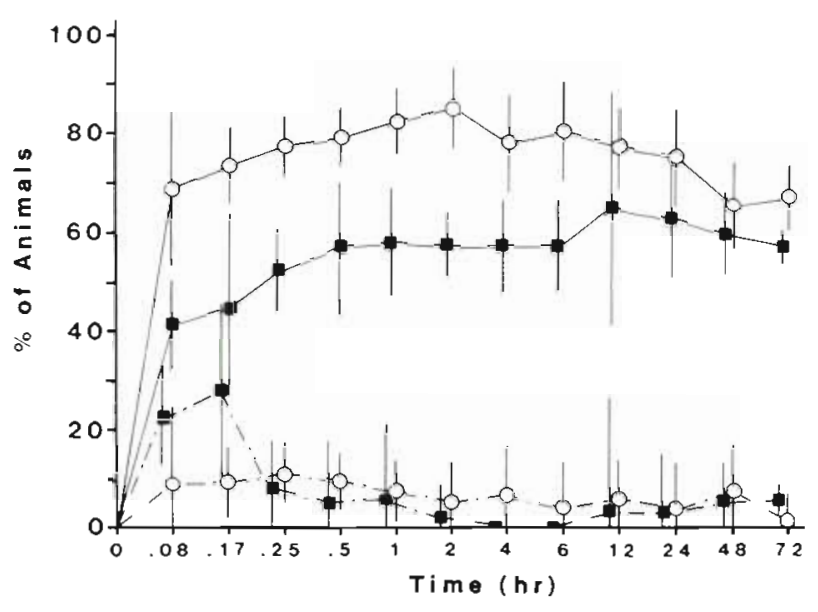

Fig. 3. Microdeutopus gryllotalpa. Age differences in patch choice over time. Mean percent $( \pm 1$ SD) of adults $(0)$ and juveniles ( $\square$ ) found on high food density patches is shown by solid line; percent of adults and juveniles not on any patch by broken lines. See Table 3

Table 4. Microdeutopus gryllotalpa. Comparison of adult and juvenile abilities to discriminate between patches of different sediment thickness. All experiments were run in black dish arenas, except E (large Petri dish arenas), and were replicated 4 to 5 times ( 20 amphipods of one age per replicate). Experiments ran $48 \mathrm{~h}$. Both amphipod age classes failed to respond to differences in patches when both patches $\geq 3 \mathrm{~mm}$

\begin{tabular}{|c|c|c|c|}
\hline \multirow[t]{2}{*}{ Expt } & \multirow[t]{2}{*}{$\begin{array}{l}\text { Sediment depths } \\
\text { (mm) }\end{array}$} & \multicolumn{2}{|c|}{$\begin{array}{c}\text { Percent of individuals } \\
\text { on deeper patch } \\
\text { (Mean, SD, N, Significance) }\end{array}$} \\
\hline & & Adults & Juveniles \\
\hline $\mathrm{A}$ & $10 \mathrm{~mm}$ vs $5 \mathrm{~mm}$ & $\begin{array}{c}53.90 \\
( \pm 17.40) \\
5 \\
n s\end{array}$ & $\begin{array}{c}43.91 \\
\pm 19.49) \\
5 \\
n s\end{array}$ \\
\hline $\mathrm{B}$ & $5 \mathrm{~mm}$ vs $3 \mathrm{~mm}$ & $\begin{array}{c}45.19 \\
( \pm 11.26) \\
5 \\
n s\end{array}$ & $\begin{array}{c}49.75 \\
( \pm 19.04) \\
5 \\
\text { ns }\end{array}$ \\
\hline $\mathrm{C}$ & $5 \mathrm{~mm}$ vs $1 \mathrm{~mm}$ & $\begin{array}{c}91.10 \\
( \pm 8.25) \\
5 \\
\mathrm{p} \leq 0.001\end{array}$ & $\begin{array}{c}69.43 \\
( \pm 9.41) \\
5 \\
p \leq 0.001\end{array}$ \\
\hline $\mathrm{D}$ & $3 \mathrm{~mm} \mathrm{vs} 1 \mathrm{~mm}$ & $\begin{array}{c}64.55 \\
( \pm 8.89) \\
4 \\
p \leq 0.01\end{array}$ & $\begin{array}{c}64.88 \\
( \pm 14.94) \\
5 \\
p \leq 0.001\end{array}$ \\
\hline$E$ & $0.5 \mathrm{~mm} v s \quad 0.2 \mathrm{~mm}$ & $\begin{array}{c}94.74 \\
( \pm 10.53) \\
4 \\
p \leq 0.001\end{array}$ & $\begin{array}{c}98.75 \\
( \pm 2.50) \\
4 \\
p \leq 0.001\end{array}$ \\
\hline $\mathrm{F}$ & $\begin{array}{l}5 \mathrm{~mm} \text { vs } 5 \mathrm{~mm} \\
\text { (Equal depth } \\
\text { control) }\end{array}$ & $\begin{array}{c}50.00 \\
( \pm 14.57) \\
4 \\
n s\end{array}$ & $\begin{array}{c}47.75 \\
\pm 28.54) \\
4 \\
n s\end{array}$ \\
\hline
\end{tabular}


food and low food patches over time: Chl a concentration ( $\mu \mathrm{g} \mathrm{Chl} \mathrm{a} \mathrm{g}{ }^{-1} \mathrm{DCS}$ ) of high food patches dropped from 45.0 to 14.0 and rose slightly (5.0 to 6.2) in low food patches. Patch occupancy was high throughout the $72 \mathrm{~h}$ of the experiment; 89 to $98 \%$ of adults and 71 to $100 \%$ of juveniles resided on some patch.

\section{Sediment depth selection}

Amphipods of both age classes consistently chose deeper patches, when any discrimination was evident (Table 4). Both age classes favored the deeper patches in choices between 5 and $1 \mathrm{~mm}, 3$ and $1 \mathrm{~mm}$, and 0.5 and $0.2 \mathrm{~mm}$ deep patches, but showed no discrimination between 10 and $5 \mathrm{~mm}$ or 5 and $3 \mathrm{~mm}$ deep patches.

Patch selection for topographic relief

Both adults and juveniles chose sediments containing solid structures (i.e. ridges, crevices, or layers of screen) to sediments lacking such topographic relief (Table 5). Adults detected ridges buried approximately $2 \mathrm{~mm}$ below the sediment surface and settled on the side of the arenas containing these buried structures.
More adult amphipods settled in the narrow $(5 \mathrm{~mm}$ wide) crevice treatment than in the wide $(10 \mathrm{~mm}$ wide) crevice treatment when each crevice treatment covered an equal area, but not when the numbers of crevices were equal. This indicates that the selection of narrow crevices in the 'equal area' experiment was likely a consequence of the greater probability of encountering a ridge in the narrow treatment as opposed to the wide treatment. When the magnitude of vertical topographic relief was increased by stacking layers of screen, adult Microdeutopus gryllotalpa settled on the thicker screen patches, whether 2 layers or 4 layers thick, but juveniles did not express discrimination between patches 1 and 2 or 1 and 4 layers thick. In general, juveniles were less discriminating than adults, and often did not select structures over flat sediment patches (Table 5).

Simultaneous choice between 2 independent habitat variables

(1) Patch choice: Regardless of the relative or absolute amount of food in sediment patches, adult $\mathrm{Mi}$ crodentopus gryllotalpa chose deep mud patches over thin ones, when the food level was held constant between patches of different depth (Table 6A,B).

Table 5. Microdeutopus gryllotalpa. Age differences in choice of patches with variable amounts of topographic relief. X and $Y$ represent contrasting patch treatments in each experiment. Ridge detection and crevice spacing experiments were conducted in freezer box arenas with 26 adults or juveniles per replicate; experiments ran $96 \mathrm{~h}$. Crevice height experiments were run in large Petri dish arenas with $4.8 \mathrm{~cm}$ diameter patches, and 10 adults or 20 juveniles. These experiments ran $24 \mathrm{~h}$

\begin{tabular}{|c|c|c|c|c|c|c|c|c|}
\hline \multirow[b]{3}{*}{$\begin{array}{l}\text { Patch } \\
\text { treatments }\end{array}$} & \multicolumn{8}{|c|}{$\%$ of individuals on Patch $\mathrm{X}$} \\
\hline & \multicolumn{4}{|c|}{ Juveniles } & \multicolumn{4}{|c|}{ Adults } \\
\hline & Mean & $\mathrm{SD}$ & $N$ & Significance & Mean & $\mathrm{SD}$ & $\mathrm{N}$ & Significance \\
\hline $\begin{array}{l}X: \text { ridges } \\
Y: \text { no ridges }\end{array}$ & 75.3 & 9.8 & 4 & $p \leq 0.001$ & 85.8 & 10.8 & 9 & $p \leq 0.001$ \\
\hline $\begin{array}{l}\mathrm{X} \text { : buried ridges } \\
\mathrm{Y} \text { : no ridges }\end{array}$ & \multicolumn{4}{|c|}{ Not tested } & 74.6 & 21.3 & 4 & $p \leq 0.001$ \\
\hline $\begin{array}{l}X: 5 \mathrm{~mm} \text { crevices }^{1} \\
\mathrm{Y}: 10 \mathrm{~mm} \text { crevices }\end{array}$ & \multicolumn{4}{|c|}{ Not tested } & 73.4 & 17.4 & 9 & $\mathrm{p} \leq 0.001$ \\
\hline $\begin{array}{l}X: 5 \mathrm{~mm} \text { crevices }^{2} \\
\mathrm{Y}: 10 \mathrm{~mm} \text { crevices }\end{array}$ & \multicolumn{4}{|c|}{ Not tested } & 40.7 & 16.4 & 5 & ns \\
\hline $\begin{array}{l}\text { X: } 1 \text { screen layer } \\
\text { Y: } 0 \text { layers }\end{array}$ & 75.3 & 9.8 & 4 & $\mathrm{p} \leq 0.001$ & 88.0 & 8.4 & 5 & $\mathrm{p} \leq 0.001$ \\
\hline $\begin{array}{l}X: 2 \text { layers } \\
\text { Y: } 1 \text { layer }\end{array}$ & 54.1 & 21.9 & 5 & ns & 76.0 & 11.4 & 9 & $\mathrm{p} \leq 0.001$ \\
\hline $\begin{array}{l}\mathrm{X}: 4 \text { layers } \\
\mathrm{Y}: 1 \text { layer }\end{array}$ & 34.4 & 26.7 & 5 & ns & 77.1 & 6.3 & 5 & $\mathrm{p} \leq 0.001$ \\
\hline
\end{tabular}


Amphipods selected high food patches, regardless of the thickness of the sediment patch, if sediment thickness was held constant between patches of different food abundance or concentration (Table 6C, D). These results suggest that amphipods discriminated between food concentration and sediment depth independently.

(2) Colonization rate: For all population classes, amphipods took longest to colonize patches with combined, low preference habitat features (e.g. low food and thin sediment) and colonized most rapidly patches composed of combined, high preference features (e.g. high food and deep sediment) (Fig. 4A,D, respectively). Colonization rates of patches with combined high and low preference features (e.g. Fig. 4B,C) were intermediate to those of highest and lowest preference. Colonization halftimes (i.e. time until half of the individuals had colonized a patch) were significantly different between food abundance treatments and sediment depth treatments (3-way ANOVA: Between
Food Levels: $F=38.88, \mathrm{df}=1,24, \mathrm{p} \leq 0.001 ;$ Between Mud Depths: $F=39.32$, df $=1,24, p \leq 0.001$ ), but no significant interaction was found between these factors. Among the population classes, adults took longer to colonized patches than juveniles for all food and depth treatments, while males and females did not differ in their colonization behavior (same 3-way ANOVA: Among Ages \& Sexes: $F=29.07, \mathrm{df}=2,24$, $\mathrm{p} \leq 0.001$; a posteriori comparison among means: [Males $=$ Females] $>$ Juveniles). Interactions with food and sediment depth were not significant.

\section{Field experiments}

Microdeutopus gryllotalpa in the field showed distinct patch choice behavior (Table 7). Amphipods chose high food abundance patches, deep sediment patches, and patches with crevices over alternate

Table 6. Microdeutopus gryllotalpa. Choice of microhabitat patches varying independently in both sediment depth and food level (abundance or concentration). Food abundance or concentration and sediment depth are given for each patch treatment (X and $\mathrm{Y}$ ) in each experiment. $\mathrm{N}=4$ for all experiments, with 20 adult amphipods per replicate. OMA: organic mineral aggregates; DCS: dark-cultured sediment

\begin{tabular}{|c|c|c|c|c|c|c|}
\hline \multicolumn{2}{|c|}{$\begin{array}{c}\text { Food } \\
(\mathrm{ml} \text { OMA) }\end{array}$} & \multicolumn{2}{|c|}{$\begin{array}{c}\text { Depth } \\
\text { (mm of DCS) }\end{array}$} & \multicolumn{3}{|c|}{$\%$ of amphipods on deeper patch } \\
\hline$X$ & Y & $\mathrm{X}$ & Y & Mean & $\mathrm{SD}$ & Significance \\
\hline 0.0 & 0.0 & 0.2 & 0.8 & 87.4 & 11.4 & $\mathrm{p} \leq 0.001$ \\
\hline 0.5 & 0.5 & 0.2 & 0.8 & 65.5 & 12.1 & $p \leq 0.01$ \\
\hline 5.0 & 5.0 & 0.2 & 0.8 & 71.4 & 19.8 & $\mathrm{p} \leq 0.001$ \\
\hline
\end{tabular}

(B) Food concentration constant, sediment depth variable

\begin{tabular}{|c|c|c|c|c|c|c|}
\hline \multicolumn{2}{|c|}{$\begin{array}{c}\text { Food } \\
\text { (mI OMA mm }{ }^{-1} \text { DCS) }\end{array}$} & \multicolumn{2}{|c|}{$\begin{array}{c}\text { Depth } \\
\text { (mm of DCS) }\end{array}$} & \multicolumn{3}{|c|}{$\%$ of amphipods on deeper patch } \\
\hline$x$ & $\mathrm{Y}$ & $\mathrm{x}$ & $\mathrm{Y}$ & Mean & $\mathrm{SD}$ & Significance \\
\hline $2 \mathrm{ml} \mathrm{mm} m^{-1}$ & $2 \mathrm{ml} \mathrm{mm}^{-1}$ & 0.2 & 0.8 & 91.5 & 6.1 & $p \leq 0.001$ \\
\hline $20 \mathrm{ml} \mathrm{mm}^{-1}$ & $20 \mathrm{ml} \mathrm{mm}^{-1}$ & 0.2 & 0.8 & 78.6 & 22.3 & $p \leq 0.001$ \\
\hline
\end{tabular}

(C) Food abundance variable, sediment depth constant

\begin{tabular}{|c|c|c|c|c|c|c|}
\hline \multicolumn{2}{|c|}{$\begin{array}{c}\text { Food } \\
(\mathrm{ml} \mathrm{OMA})\end{array}$} & \multicolumn{2}{|c|}{$\begin{array}{c}\text { Depth } \\
(\mathrm{mm} \text { of DCS) }\end{array}$} & \multicolumn{3}{|c|}{$\%$ of amphipods on high food patch } \\
\hline $\mathrm{x}$ & $\mathrm{Y}$ & $\mathrm{X}$ & $\mathrm{Y}$ & Mean & SD & Significance \\
\hline 0.5 & 5.0 & 0 & 0 & 91.7 & 6.9 & $\mathrm{p} \leq 0.001$ \\
\hline 0.5 & 5.0 & 0.2 & 0.2 & 75.1 & 20.1 & $\mathrm{p} \leq 0.01$ \\
\hline 0.5 & 5.0 & 0.8 & 0.8 & 80.7 & 20.6 & $\mathrm{p} \leq 0.001$ \\
\hline \multicolumn{7}{|c|}{ (D) Food concentration variable, sediment depth constant } \\
\hline \multicolumn{2}{|c|}{$\begin{array}{c}\text { Food } \\
\left(\mathrm{ml} \mathrm{OMA} \mathrm{mm} \mathrm{mm}^{-1} \mathrm{DCS}\right)\end{array}$} & \multicolumn{2}{|c|}{$\begin{array}{c}\text { Depth } \\
\text { (mm of DCS) }\end{array}$} & \multicolumn{3}{|c|}{$\%$ of amphipods on high food patch } \\
\hline$X$ & $\mathrm{Y}$ & $\mathrm{X}$ & Y & Mean & $\mathrm{SD}$ & Significance \\
\hline $2 \mathrm{ml} \mathrm{mm}^{-1}$ & $20 \mathrm{ml} \mathrm{mm}^{-1}$ & 0.2 & 0.2 & 62.1 & 7.2 & $p \leq 0.05$ \\
\hline $2 \mathrm{ml} \mathrm{mm}^{-1}$ & $20 \mathrm{ml} \mathrm{mm}^{-1}$ & 0.8 & 0.8 & 81.2 & 4.2 & $\mathrm{p} \leq 0.001$ \\
\hline
\end{tabular}


Fig. 4. Microdeutopus gryllotalpa. Intraspecific variation in colonization of microhabitat patches varying independently in food abundance and sediment depth. (A) Low food and thin mud; (B) low food and deep mud; (C) high food and thin mud; (D) high food and deep mud. Mean number of amphipods not burrowed is plotted for adult males (ロ- $\mathbf{-})$, adult females $(\mathrm{O}-\mathrm{O})$, and juveniles $(\Delta--\Delta)$, in each patch type. Error bars are omitted for clarity. $\mathrm{N}=3$ or 4 with 20 adults or 30 juveniles per replicate. A single, $4.8 \mathrm{~cm}$ diameter patch of a food level/ mud depth combination was present in each replicate, large Petri dish arena

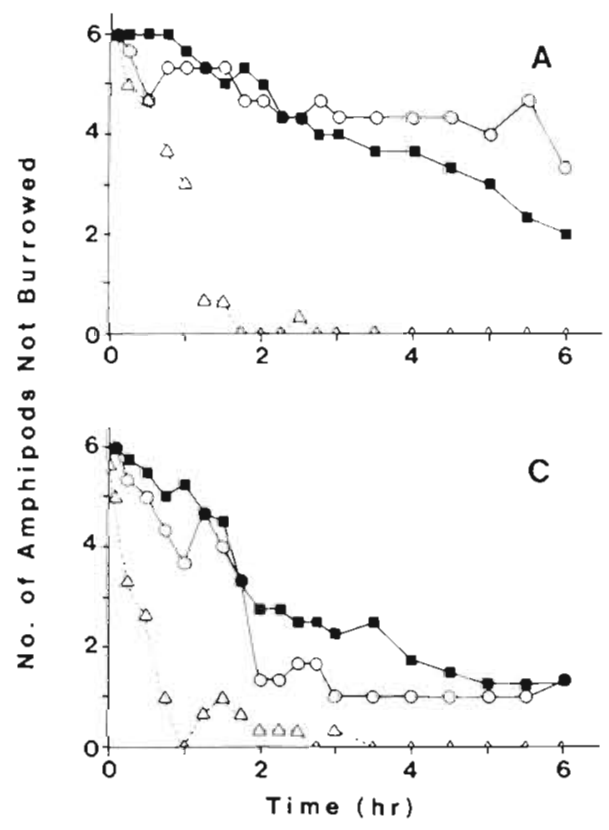

B
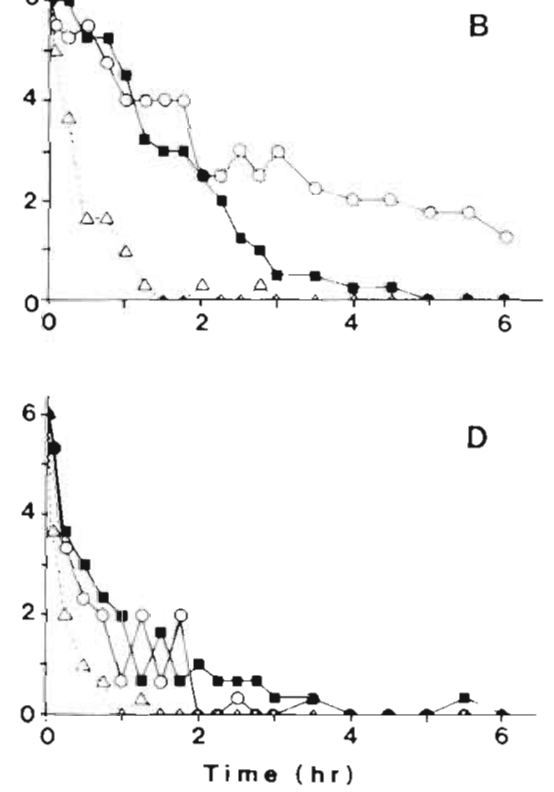

Table 7. Microdeutopus gryllotalpa. Temporal variation in colonization of habitat patches placed in the field. Number of colonists on different habitat patches after day and night placement of the experimental racks. Results of 2 sampling dates (5 to 6 Jun and 10 to 11 Jun 1984) are combined. J: juveniles; $\mathrm{M}$ : adult males; $\mathrm{F}$ : adult females

\begin{tabular}{|c|c|c|c|c|c|c|}
\hline \multirow[b]{3}{*}{ Patch type } & \multicolumn{6}{|c|}{$\begin{array}{l}\text { No. of amphipods on each } \\
\text { habitat patch }\end{array}$} \\
\hline & \multicolumn{3}{|c|}{ Day } & \multicolumn{3}{|c|}{ Night } \\
\hline & $\mathrm{J}$ & M & $\mathrm{F}$ & $\mathrm{J}$ & M & $F$ \\
\hline High food & 7 & 11 & 0 & 14 & 14 & 12 \\
\hline Low food & 2 & 4 & 1 & 5 & 11 & 3 \\
\hline Deep mud & 8 & 10 & 2 & 17 & 11 & 9 \\
\hline Thin mud & 6 & 4 & 0 & 8 & 4 & 3 \\
\hline Crevices & 12 & 12 & 3 & 14 & 14 & 16 \\
\hline No crevices & 4 & 3 & 1 & 7 & 2 & 1 \\
\hline Total & 39 & 44 & 7 & 65 & 56 & 44 \\
\hline
\end{tabular}

patches for each habitat feature (G-test goodness-of-fit to a $1: 1$ distribution; all $p \leq 0.001$ ). There were significant differences in the numbers of juvenile, male, and female colonists (fewer females) (2-way ANOVA: Among Ages \& Sexes: $F=12.74, \mathrm{df}=2,30, \mathrm{p} \leq 0.001$; post-hoc comparison of means: [Males = Juveniles] $>$ Females), and the time of day (more nocturnal colonists) (same 2-way ANOVA: Between Times of Day: $\mathrm{F}=28.14$, $\mathrm{df}=1,30, \mathrm{p} \leq 0.001)$; there was no significant interaction between these factors. As there was no physical connection between the fouling-community population(s) and the experimental racks, the patches must have been colonized by swimming amphipods.
The total area of the 16 field deployed arenas was $1491.1 \mathrm{~cm}^{2}$. An average of 45 Microdeutopus gryllotalpa colonized all of this space during $12 \mathrm{~h}$ daylight and 82.5 amphipods colonized over 8 h at night (Table 7). Extrapolating to $1 \mathrm{~d}$ periods, colonization rates ranged from 0.06 amphipods $\mathrm{cm}^{-2} \mathrm{~d}^{-1}$ (daylight) to $0.17 \mathrm{~cm}^{-2}$ $\mathrm{d}^{-1}$ (night). This is a conservative estimate since much of the large Petri plates were bare and presumably unsuitable for colonization.

\section{DISCUSSION}

Previous studies have identified several habitat features that influence habitat selection in juvenile and adult benthic invertebrates (see Meadows \& Campbell 1972 for examples). Many other aspects of habitat selection have not received attention, however, including rates of choosing among microhabitats, intraspecific variation in patch choice, thresholds in patch discrimination, simultaneous discrimination among several habitat variables, and habitat selection in the field. These points were addressed in this study.

\section{Microhabitat choices in the laboratory and field}

Microdeutopus gryllotalpa generally chose patches with higher microfloral concentrations, thicker sediments, and greater topographic relief. The microhabitat selection behavior of $M$. gryllotalpa is comparable to that of other amphipods (Meadows \& Reid 1966, Stoner 1980, Oakden et al. 1984) and other inverte- 
brates (Meadows \& Campbell 1972). Microhabitat choice behavior is apparently adaptive to this species since growth rate, survival, and fecundity are positively correlated with preferred habitats under laboratory conditions (DeWitt 1985).

Patch choices demonstrated in the laboratory were also expressed by individuals in the field. Most of the colonization in the field occurred at night when relatively more of these amphipods emerge from the benthos (DeWitt 1985). Males and juveniles predominated as colonists. The degree to which microhabitat selection behavior influences the spatial distribution of Microdeutopus gryllotalpa in the wild was not examined, but its potential contribution is certainly evident from these experiments. Benthic microhabitats are spatially variable with regard to physical structure, biotic composition, and food abundance (Bunt et al. 1972, Grant et al. 1986), although few studies have measured microhabitat variability in marine sediments. Along the coasts of Long Island, M. gryllotalpa is primarily a member of the fouling community (i.e. on floating docks, eelgrass blades, in mussel clumps, etc.) where the sediment layer is generally thin, yet it prefers deeper sediments. Fouling communities have considerably more topographic structure than mudflats and may represent either a preferred habitat, satisfactory refuge from biogenic disturbances intrinsic to local mudflats (e.g. the mudsnail llyanassa obsoleta; DeWitt \& Levinton 1985, Levinton et al. 1985), or the only habitats from which the amphipods are not eliminated by predators or lethal disturbance. The first 2 mechanisms are not mutually exclusive, and the first (habitat selection behavior) could have evolved as a consequence of the second (escape from stress).

\section{Limitations in patch discrimination behavior}

Microdeutopus gryllotalpa did not always discriminate between qualitatively different microhabitat patches. This could have resulted from (1) inability to distinguish between patches, (2) thresholds in 'decision-making' whereby the amphipods evaluate contrasting patches as being sufficiently similar so as to be treated identically (i.e. indifference to the habitat variable treatments), or (3) experimental failure to create qualitatively different patches. As failure to discriminate between non-control patches was repeatedly observed in experiments involving each of the habitat variables, I feel reasonably confident in eliminating experimental failure. It is not possible to distinguish between the first 2 mechanisms at this time.

For patches differing in food concentration, limitations of patch discrimination were most pronounced when minimal differences existed between patches
(Table 2); no upper boundary to discrimination of high food abundance was observed even between patches of 'undiluted' OMA (Table 6C). However, lower concentrations of Ulva and fish food were chosen over high concentrations of these foods. Avoidance of sediments spiked with fish food or Ulva may be a response to local anoxic conditions derived from the decomposition of these rich sediments or toxic exudates of Ulva (Johnson \& Welsh 1985).

Microdeutopus gryllotalpa did not discriminate between patches greater than $3 \mathrm{~mm}$ thick, but did distinguish between very thin patches marginally different in thickness (Table 4). As sediment depth increases, protection from epifaunal predators and biogenic, sediment surface disturbers increases (Blundon \& Kennedy 1982, DeWitt \& Levinton 1985). As sediment depth decreases, less material is available to construct tubes. It seems reasonable that the amphipods should prefer the thickest available patch.

Although some amphipods may not discriminate between sediments of different depth (Stretch 1985), Meadows (1964) found that Corophium volutator chose deeper sediments, discriminating between patches $5 \mathrm{~mm}$ deep and patches 20 to $90 \mathrm{~mm}$ deep, but not between patches greater than $20 \mathrm{~mm}$ deep. As larger C. volutator selected deeper sediments than did smaller individuals, Meadows (1964) suggested that depth selection may reflect a body-size dependent minimum burrow length which is necessary for effective feeding behavior. Intraspecific differences in depth choice behavior were not observed in Microdeutopus gryllotalpa. Possibly $M$. gryllotalpa cannot distinguish patch differences when the sediment is thicker than ca $3 \mathrm{~mm}$ because of an inability to probe below sediment of that depth. Prior to burrowing and tube building, $M$. gryllotalpa dip their antennae and gnathopods into the sediment (pers. obs.), possibly to probe for solid structures in the sediment. These appendages are less than $3 \mathrm{~mm}$ long in the individuals used in these experiments (they average less than half the body length for all body sizes). Meadows (1964) suggested that $C$. volutator probes sediment thickness with its enlarged second antennae, which increases allometrically in length relative to body size, particularly in males (J. Chapman pers. comm.). As the length of the antennae of $M$. gryllotalpa are approximately linearly proportional to body size (author's obs.), this may explain why age differences in depth choice were not expressed.

Adult Microdeutopus gryllotalpa always colonized patches with greater topographic relief, while juveniles failed to chose between patches as long as some vertical relief was present (Table 5). Small-scale solid structures provide adult Microdeutopus with refuge from sediment surface disturbance and predation 
(DeWitt 1985, DeWitt \& Levinton 1985), much as larger structures do for other benthic invertebrates (Woodin 1978, Stoner 1980). No upper or lower topographic choice thresholds were observed for adults, but only a few combinations of relief were tested. Juveniles appear to have an absolute, rather than relative, preference for solid structure which may be a consequence of their vulnerability to predators (Watzin 1983), lack of experience, or thresholds that were exceeded by the magnitude of topographic relief which were presented in these experiments.

\section{Simultaneous discrimination between different habitat variables}

The experiments on the interaction between food concentration and sediment thickness during patch choice (Table 6) and colonization rate (Fig. 4) suggest that Microdeutopus gryllotalpa evaluates each of these sediment features independently and that both have equivalent influence on total habitat quality. When a colonizing benthic invertebrate encounters a habitat patch, several sedimentary features influence patch suitability. Previous studies on microhabitat choice have not examined simultaneous selection between dissimilar habitat factors. The present study suggests that an additive model adequately describes how $M$. gryllotalpa ranks habitat quality when evaluating more than one habitat variable. That is, the total suitability of a patch may be a function of the sum of the quality of the habitat variables encountered. This is an exciting area for further research and could draw upon analogous work in experimental psychology (see Chapter 7 of Staddon 1983).

\section{Rate of habitat selection and colonization}

Microdeutopus gryllotalpa generally selected habitat patches rapidly. Within $5 \mathrm{~min}$ of being presented with a choice of high and low food abundance patches, 75 to $91 \%$ of test specimens settled, with 55 to $75 \%$ of these colonists occupying high food patches. M. gryllotalpa in the field also colonized experimental patches rapidly: 0.06 (daylight) to 0.17 (night) individuals settling $\mathrm{cm}^{-2} \mathrm{~d}^{-1}$. These colonization rates are similar to rates observed for adult and juvenile benthic invertebrates (Alldredge \& King 1980, VanBlaricom 1982, Bell \& Devlin 1983, Levin 1984, Oliver \& Slattery 1985) and are comparable to larval colonization rates (Hannan 1984, Levin 1984). Furthermore, a majority of the individuals in the communities examined in these studies belong to species that can colonize habitats as adults or juveniles. This suggests that for many taxa and benthic habitats, dispersal and colonization by juvenile and adult stages may be at least as important as larval colonization in determining benthic community composition.

Rapid discrimination and colonization of sediment patches may permit Microdeutopus grylotalpa to avoid benthic predators or disturbance (DeWitt \& Levinton 1985), and to occupy patches of the highest available quality. Rapid colonization of disturbed sediments or food-rich deposits (e.g. seaweed or carcasses) also may provide adults and juveniles with access to under utilized resources, especially if food (Levinton \& Lopez 1977, Whitlatch 1980) or space (Peterson 1977, Levin 1981) are limiting. Coupled with the ability to discriminate the best available microhabitats, high colonization rates should result in rapid localized population growth of colonists. For example, Zajac \& Whitlatch (1982, pers. comm.) observed that sediment cores were rapidly colonized by adult $M$. gryllotalpa, and often contained high densities of juveniles released by colonizing females.

\section{Intraspecific differences in habitat selection behavior}

Colonization rates differed between age classes but not between sexes. Patch selection behavior of males and females may differ due to the presence of mates or individuals of the same sex (Borowsky 1980, 1983, 1984), but apparently does not differ with respect to environmental features of microhabitats. Juveniles generally colonized patches of any type more rapidly than adults, but adults discriminated among patches faster and better than juveniles (Fig. 2 to 4 ). Juveniles may face a greater risk from predation than adults (e.g. juveniles confront both meiofaunal and macrofaunal predators (Watzin 1983]), and age differences in colonization and habitat selection behavior may be the result of selection against behavior that exposes juveniles to risk, even at the cost of occupying habitats of low quality.

Juveniles of other amphipod species generally are not as common nocturnal emigrants as are adults (Robertson \& Howard 1978), and adults are predominant among post-larval colonists of disturbed sediments (Santos \& Simon 1980, VanBlaricom 1982). In the laboratory, juvenile Microdeutopus gryllotalpa (Kafka \& Borowsky 1985) and other amphipods (Skutch 1926, Sheader 1978) usually construct tubes very close to the tubes of their mothers, and travel very little away from these tubes, even in low quality habitats (DeWitt 1985, Borowsky pers. comm.). In the field, juveniles were nearly as common as adults in colonizing experimental patches. Juveniles are readily displaced from their tubes by larger animals (Borowsky 1980, 1983, 
author's obs.), and it is possible that the observed high rates of colonization resulted from juveniles being evicted from crowded patches.

\section{CONCLUSION AND SPECULATIONS}

The ability of adult and juvenile Microdeutopus gryllotalpa to discriminate among microhabitats suggests that habitat selection is important in determining its spatial distribution. Intraspecific differences in colonization and patch choice behavior indicate that this ability is relatively greater in adults. Patch quality affects somatic growth, survival, fecundity, and susceptibility to predation (DeWitt 1985) and influences colonization and emigration rates (Ambrose 1984, DeWitt 1985). The rates at which adult and juvenile benthic invertebrates can discriminate among microhabitats and colonize new patches points to the need to examine these processes on time scales of hours and days, and spatial scales of millimeters, as argued previously by Santos \& Simon (1980), Bell \& Devlin (1983), and Eckman (1979).

The scale of patchiness to which habitat-seeking benthic invertebrates respond is not well known. In these experiments, contrasting microhabitat patches were spaced less than $8 \mathrm{~cm}$ apart. Patchiness of habitats in the field can vary from sand grains to kilometers, depending on the magnitude of disturbance or how one defines a patch. Few studies have measured the patchiness of sediment microhabitats, but those examining the spatial distribution of sediment microflora found significant differences in microalgal abundance in patches centimeters (Grant et al. 1986) and meters apart (Bunt et al. 1972; sampling along a depth gradient).

Colonization of disturbed patches by juveniles and adults may approximate a diffusion process, with colonists entering from source habitats surrounding the site of disturbance. Field experiments show that small to moderate-scale disturbances (i.e. patches less than $10 \mathrm{~m}$ across) are rapidly colonized by juveniles and adults, and relatively more slowly by larvae (VanBlaricom 1982, Bell \& Devlin 1983, Levin 1984, Oliver \& Slattery 1985). However, large-scale disturbances are slower to recover (Santos \& Simon 1980), perhaps because (1) colonization moves from the perimeter inward: colonists enter from the patch perimeter and occupy the first suitable microhabitats close to the perimeter; sediments at the patch center are colonized last. And (2) the patch is so large that surrounding source habitats cannot supply enough colonists to fill the patch rapidly. Edgar (1983) and Virnstein \& Curran (1986) demonstrated that rates of amphipod colonization of macroalgal and seagrass patches decreased as the distance from the source of colonists increased.
Models of benthic community and population structure should be modified to incorporate migration, colonization, and habitat selection by adult and juvenile invertebrates. Much work remains to be done to determine the importance of emergence and habitat selection behavior since most studies to date have only reported patterns of macrofaunal emergence and speculate that these activities potentially influence population and community structure. These short-term and high-frequency phenomena are an under-appreciated alternative to larval recruitment and mortality as mechanisms responsible for changes in the distribution and abundance of benthic species. Emergence into the water column or sediment surface may be a common escape from environmental stress (including disturbance, predation, competition, and contamination). Emergence coupled with juvenile-adult colonization can lead to rapid changes in spatial and demographic distribution of benthic species. Although predation, disturbance, resource exploitation, and antagonism among neighbors may ultimately drive emigration and colonization, these forces may not necessarily lead to the death of the target animals but thrust them into a game of musical chairs.

Acknowledgements. I thank B. Borowsky, G. Hechtel, J. Levinton, and G. Lopez for thoughtful reviews of an earlier version of the manuscript, and I am grateful to J. Chapman, R. Lipcius, R. Swartz, R. Whitlatch and 3 anonymous reviewers for their helpful comments on recent versions. I am indebted to D. Berg, M. Campbell, D. Hersh, A. Vilella, and N. Yamamoto for assistance in the laboratory and field. I also thank my dissertation advisors, J. Levinton and G. Lopez for their advice and logistical support during this research, and R. Swartz for support during the preparation of this manuscript.

\section{LITERATURE CITED}

Åkesson, B., Ehrenström, F. (1984). Avoidance reactions of Dorvilleid polychaetes to chemical-contaminated sediments. In: Persoone, G., Jaspers, E., Claus, C. (ed.) Ecotoxicological testing for the marine environment, Vol. 2. State Univ. Ghent and Inst. Mar. Scient. Res., Bredene, Belgium, p. $3-12$

Alldredge, A. L., King, J. M. (1977). Distribution, abundance, and substrate preferences of demersal reef zooplankton at Lizard Island Lagoon, Great Barrier Reef. Mar. Biol. 41 $317-333$

Alldredge, A. L., King, J. M. (1980). Effects of moon light on the vertical migration patterns of demersal zooplankton. $J$. exp. mar. Biol. Ecol. 44: 133-156

Ambrose, W. G., Jr. (1984). Increased emigration of the amphipod Rhepoxynius abronius (Barnard) and the polychaete Nephtys caeca (Fabricius) in the presence of predators. J. exp. mar. Biol. Ecol. 80: 67-75

Ambrose, W. G., Jr. (1986). Experimental analysis of density dependent emigration of the amphipod Rhepoxynius abronius. Mar. Behav. Physiol. 12: 209-216

Anger, K., Valentin, C. (1976). In situ studies on the diurnal 
activity pattern of Diastylis rathkei (Cumacea, Crustacea) and its importance for the 'hyperbenthos'. Helgoländer wiss. Meeresunters. 28: 138-144

Bell, S. S., Devlin, D. J. (1983). Short-term macrofaunal recolonization of sediment and epibenthic habitats in Tampa Bay, Florida. Bull. mar. Sci. 33: 102-108

Beukema, J. J., de Vlas, J. (1979). Population parameters of the lugworm, Arenicola marina, living on tidal flats in the Dutch Wadden Sea. Neth. J. Sea Res. 13: 331-353

Blundon, J. A., Kennedy, V. S. (1982). Refuges for infaunal bivalves from blue crabs, Callinectes sapidus (Rathbun), predation in Chesapeake Bay. J. exp. mar. Biol. Ecol. 65: $67-81$

Borowsky, B. (1980). The pattern of tube-sharing in Microdeutopus gryllotalpa (Crustacea: Amphipoda). Anim. Behav. 28: 790-797

Borowsky, B. (1983). Behaviors associated with tube-sharing in Microdeutopus gryllotalpa (Costa) (Crustacea: Amphipoda). J. exp. mar. Biol. Ecol. 68: 39-51

Borowsky, B. (1984). Effects of receptive females' secretions on some male reproductive behaviors in the amphipod crustacean Microdeutopus gryllotalpa. Mar. Biol. 84: 183-187

Bousfield, E. L. (1973). Shallow-water Gammaridean Amphipoda of New England. Cornell University Press, Ithaca, New York

Bunt, J. S., Lee, C. C., Lee, E. (1972). Primary productivity and related data from tropical and subtropical marine sediments. Mar. Biol. 16: 28-36

Dauer, D., Ewing, R. M., Sourbeer, J. W., Harlan, W. T., Stokes, T. L., Jr. (1982). Nocturnal movements of the macrobenthos of the Lafayette River, Virginia. Int. Revue ges. Hydrobiol. 67: 761-775

Dean, D. (1978a). Migration of the sand worm Nereis virens during winter nights. Mar. Biol. 45: 165-173

Dean, D. (1978b). The swimming of bloodworms (Glycera spp.) at night, with comments on other species. Mar. Biol. 48: 99-104

DeWitt, T. H. (1985). The behavior and ecology of migration and colonization in the epibenthic, tubicolous amphipod, Microdeutopus gryllotalpa. Ph.D. dissertation, State Univ. of New York, Stony Brook

DeWitt, T. H., Levinton, J. S. (1985). Disturbance, emigration, and refugia: how the mudsnail, Ilyanassa obsoleta, affects the habitat distribution of an epifaunal amphipod, Microdeutopus gryllotalpa. J. exp. mar. Biol. Ecol. 92: 97-113

Dobbs, F. C., Vozarik, J. M. (1983). Immediate effects of a storm on coastal infauna. Mar. Ecol. Prog. Ser. 11: 273-279

Eckman, J. E. (1979). Small-scale patterns and processes in a soft-substratum, intertidal community. J. mar. Res. 37: $437-457$

Edgar, G. J. (1983). The ecology of south-east Tasmanian phytal animal communities. IV. Factors affecting the distribution of ampithoid amphipods among algae. J. exp. mar. Biol. Ecol. 70: 205-225

Grant, J., Bathmann, U. V., Mills, E. L. (1986). The interaction between benthic diatom films and sediment transport. Estuar. coast. Shelf Sci. 23: 225-238

Hannan, C. A. (1984). Planktonic larvae may act like passive particles in turbulent near-bottom flows. Limnol. Oceanogr. 29: 1108-1116

Hurlbert, S. H. (1984). Pseudoreplication and the design of ecological field experiments. Ecol. Monogr. 54: 187-211

Jensen, K. T. (1985). The presence of the bivalve Cerastoderma edule affects migration, survival and reproduction of the amphipod Corophium volutator. Mar. Ecol. Prog. Ser. 25: 265-277
Johnson, D. A., Welsh, B. L. (1985). Detrimental effects of Ulva lactuca (L.) exudates and low oxygen on estuarine crab larvae. J. exp. Mar. Biol. Ecol. 86: 73-83

Johnson, R. G. (1974). Particulate matter at the sedimentwater interface in coastal environments. J. mar. Res. 32: 313-330

Kafka, M., Borowsky, B. (1985). Dispersal of hatched juveniles of the amphipod crustacean Microdeutopus gryllotalpa (Costa). Am. Zool. 25: 59A

Levin, L. A. (1981). Interference interactions among tubedwelling polychaetes in a dense infaunal assemblage. J. exp. mar. Biol. Ecol. 65: 107-119

Levin, L. A. (1984). Life history and dispersal patterns in a dense infaunal polychaete assemblage: community structure and response to disturbance. Ecology 65: 1185-1200

Levinton, J. S., Lopez, G. R. (1977). A model of renewable resources and limitation of deposit-feeding benthic populations. Oecologia (Berl.) 31: 177-190

Levinton, J. S., Stewart, S., DeWitt, T. H. (1985). Field and laboratory experiments on interference between Hydrobia totteni and Ilyanassa obsoleta (Gastropoda) and its possible relation to seasonal shifts in vertical mudflat zonation. Mar. Ecol. Prog. Ser. 22: 53-58

Meadows, P. S. (1964). Experiments on substrate selection by Corophium volutator (Pallas): depth selection and population density. J. exp. Biol. 41: 677-687

Meadows, P. S., Campbell, J. I. (1972). Habitat selection by aquatic invertebrates. Adv. mar. Biol. 10: 271-382

Meadows, P. S., Reid, A. (1966). The behavior of Corophium volutator (Crustacea: Amphipoda). J. Zool., Lond. 150: 387-399

Myers, A. A. (1969). A revision of the amphipod genus Microdeutopus Costa (Gammaridea: Aoridae). Bull. Br. Mus. nat. Hist. (Zool.) 17: 93-148

Myers, A. A. (1971). Breeding and growth in laboratoryreared Microdeutopus gryllotalpa Costa (Amphipoda: Gammaridea). J. nat. Hist. 5: 271-277

Oakden, J. M., Oliver, J. S., Flegal, A. R. (1984). Behavioral responses of a phoxocephalid amphipod to organic enrichment and trace metals in sediment. Mar. Ecol. Prog. Ser. 14: $253-257$

Ohlhorst, S. L. (1982). Diel migration patterns of demersal reef zooplankton. J. exp. mar. Biol. Ecol. 60: 1-15

Oliver, J. S., Slattery, P. N. (1985). Destruction and opportunity on the sea floor: effects of gray whale feeding. Ecology 66: $1965-1975$

Parker, R. H. (1975). The study of benthic communities: a model and a review. Elsevier, Amsterdam

Peterson, C. H. (1977). Competitive organization of the softbottom macrobenthic communities of southern California lagoons. Mar. Biol. 43: 343-359

Rhoads, D. C., Young, D. K. (1970). The influence of depositfeeding organisms on sediment stability and community trophic structure. J. mar. Res. 28: 150-178

Robertson, A. I., Howard, R. K. (1978). Diel trophic interactions between vertically migrating zooplankton and their fish predators in an eelgrass community. Mar. Biol. 48: $207-213$

Santos, S. L., Simon, J. L. (1980). Marine soft bottom community establishment following annual defaunation: larval or adult recruitment? Mar. Ecol. Prog. Ser. 2: 235-241

Sheader, M. (1978). Distribution and reproductive biology of Corophium insidiosum (Amphipod) on the northeast coast of England. J. mar, biol. Ass. U.K. 58: 585-596

Sherman, K. M., Coull, B. C. (1980). The response of meiofauna to sediment disturbance. J exp. mar. Biol. Ecol. 46: $59-71$ 
Skutch, A. F. (1926). On the habits and ecology of the tubebuilding amphipod Ampithoe rubricata Montagu. Ecology 7: $482-502$

Sokal, R. R., Rohlf, F. J. (1981). Biometry, 2nd edn. W. H. Freeman, San Francisco

Staddon, J. E. R. (1983). Adaptive behavior and learning. Cambridge University Press, New York

Stoner, A. W. (1980). Perception and choice of substratum by epifaunal amphipods associated with seagrasses. Mar. Ecol. Prog. Ser. 3: 105-111

Stretch, J. J. (1983). Habitat selection and vertical migration of sand-dwelling demersal gammarid amphipods. Ph.D. dissertation, Univ. of Califomia, Santa Barbara

Stretch, J. J. (1985). Quantitative sampling of demersal zooplankton: reentry and airlift dredge sample comparisons. J. exp. mar. Biol. Ecol. 91: 125-136

Strickland, J. D. H., Parsons, T. R. (1969). A practical handbook of seawater analysis. Bull. Fish. Res. Bd Can. 167

Thorson, G. (1966). Some factors influencing the recruitment and establishment of marine benthic communities. Neth. J. Sea Res. 3: 267-293

VanBlaricom, G. R. (1982). Experimental analyses of structural regulation in a marine sand community exposed to oceanic swell. Ecol. Monogr. 52: 283-305

Virnstein, R. W., Curran, M. C. (1986). Colonization of artificial seagrass versus time and distance from source. Mar.
Ecol. Prog. Ser. 29: 279-288

Vollenweider, R. A. (1969). A manual on the methods for measuring primary productivity in aquatic environments. I.B.P. Handbook No. 12. Blackwell Sci. Publ., Oxford

Walters, K., Bell, S. S. (1986). Diel patterns of active migration in seagrass meiofauna. Mar. Biol. (in press)

Watzin, M. C. (1983). The effects of meiofauna on settling macrofauna: meiofauna may structure macrofaunal communities. Oecologia (Berl.) 59: 163-166

Weinberg, J. R. (1979). Ecological determinants of spionid distributions within dense patches of deposit-feeding polychaete Axiothella rubrocincta. Mar. Ecol. Prog. Ser. 1: 301-314

Whitlatch, R. B. (1980). Patterns of resource utilization and coexistence in marine intertidal deposit-feeding communities, J. mar. Res. 38: 743-765

Williams, A. B., Bynum, K. H. (1972). A ten-year study of meroplankton in North Carolina estuaries: amphipods. Chesapeake Sci. 13: 175-192

Woodin, S. A. (1978). Refuges, disturbance, and community structure: a marine soft-bottom example. Ecology 59: 274-284

Zajac, R. N., Whitlatch, R. B. (1982). Responses of estuarine infauna to disturbance. II. Spatial and temporal variation of succession. Mar. Ecol. Prog. Ser. 10: 15-27 